\title{
The Potential of Esteya spp. for the Biocontrol of the Pinewood Nematode, Bursaphelenchus xylophilus
}

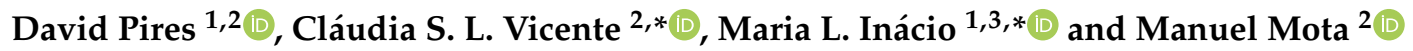 \\ 1 Instituto Nacional de Investigação Agrária e Veterinária (INIAV, I.P.), 2780-159 Oeiras, Portugal; \\ david.pires@iniav.pt \\ 2 Mediterranean Institute for Agriculture, Environment and Development (MED), University of Évora, \\ Pólo da Mitra, Apartado 94, 7006-554 Evora, Portugal; mmota@uevora.pt \\ 3 GREEN-IT Bioresources for Sustainability, ITQB NOVA, Av. da República, 2780-157 Oeiras, Portugal \\ * Correspondence: cvicente@uevora.pt (C.S.L.V.); lurdes.inacio@iniav.pt (M.L.I.)
}

check for updates

Citation: Pires, D.; Vicente, C.S.L.; Inácio, M.L.; Mota, M. The Potential of Esteya spp. for the Biocontrol of the Pinewood Nematode, Bursaphelenchus xylophilus. Microorganisms 2022, 10, 168. https://doi.org/10.3390/ microorganisms10010168

Academic Editor: Essaid Ait Barka

Received: 15 December 2021

Accepted: 12 January 2022

Published: 13 January 2022

Publisher's Note: MDPI stays neutral with regard to jurisdictional claims in published maps and institutional affiliations.

Copyright: (c) 2022 by the authors. Licensee MDPI, Basel, Switzerland. This article is an open access article distributed under the terms and conditions of the Creative Commons Attribution (CC BY) license (https:/ / creativecommons.org/licenses/by/ $4.0 /)$.

\begin{abstract}
The pinewood nematode (PWN), Bursaphelenchus xylophilus, is the causal agent of pine wilt disease (PWD) and a quarantine organism in many countries. Managing PWD involves strict regulations and heavy contingency plans, and present climate change scenarios predict a spread of the disease. The urgent need for sustainable management strategies has led to an increasing interest in promising biocontrol agents capable of suppressing the PWN, like endoparasitic nematophagous fungi of the Esteya genus. Here, we review different aspects of the biology and ecology of these nematophagous fungi and provide future prospects.
\end{abstract}

Keywords: Bursaphelenchus xylophilus; pine wilt disease; nematophagous fungi; biological control; Esteya

\section{Introduction}

The pinewood nematode (PWN), Bursaphelenchus xylophilus (Steiner and Buhrer, 1934) Nickle, 1970, is the causal agent of pine wilt disease (PWD) and a quarantine organism in many countries [1-3]. It is thought to be native to North America, where autochthonous pine species show some degree of tolerance, in contrast to exotic species that are usually susceptible to the nematode. The PWN is considered the sixth most economically important plant-parasitic nematode [4] and a major threat to pine forests worldwide, especially in Asia and Europe. Bursaphelenchus xylophilus is carried and transmitted by pine sawyer beetles belonging to the Monochamus genus [5,6]. There are currently 13 species of Monochamus known to be vectors of the PWN worldwide [7,8]. Due to its economic importance and worldwide dissemination, an enormous effort has been devoted to understand which factors play a determinant role in the epidemiology of PWD [9]. The disease results from complex interactions between the nematode, its insect vector and host plants (mostly Pinus spp.), the nematode being the common element in this interaction [10-12]. Management of PWD involves strict regulations and heavy contingency plans, resulting in the felling, removal and destruction of infected trees, with limited effectiveness [13], having a serious economic impact on the exploration and commercialization of timber and other wood products [14-16]. Aside from the economic setback, PWD threatens biodiversity, disrupts forest ecosystems and hampers resilience to climate change [17,18]. In fact, current scenarios strongly suggest that increasing temperatures and climate change are likely going to result in a prevalence of the PWN and spread of PWD to areas free of the disease [19-21]. Consequently, the urgent need for sustainable management strategies has led to an increasing interest in organisms capable of suppressing the PWN [22-24]. The endoparasitic nematophagous fungi of the Esteya genus are reported as natural enemies of the PWN and promising biocontrol agents. There are currently two described species: E. vermicola [25] and E. floridanum [26]. These PWN antagonists have received great interest 
as biocontrol agents [27]. Esteya vermicola was successful in suppressing the PWN both in greenhouse experiments [28] and field assays [29]. On the other hand, E. floridanum was able to kill PWNs in vitro but only delayed the death of trees in vivo [26], so more research is needed to assess its potential in controlling the PWN. Since its discovery, E. vermicola has been patented in the United States and South Korea as a promising option for the management of PWD [25,30,31]. Here, we review current research on the taxonomy, phylogeny, morphology, distribution and host range of Esteya spp., molecular mechanisms behind their parasitism, application of Esteya spp. to improve PWD management and future perspectives.

\section{Taxonomy, Morphology and Distribution of Esteya Species}

Esteya is a ubiquitous fungal genus belonging to the Ophiostomatales order (Ascomycota, Sordariomycetes), with only two species currently described, E. vermicola [25] and E. floridanum [26], isolated from different substrates around the world. As members of the Ophiostomataceae family, mitochondrial genome comparisons show that Esteya spp. are closely-related to Sporothrix [32] and share similar characteristics to other fungi of the same family: a saprophytic lifestyle and endophytic to weakly phytopathogenic. However, some species have been reported to kill healthy trees when the inoculum is too high [33].

\subsection{Taxonomy and Phylogeny}

The first isolate of E. vermicola was deposited as Lunuromyces thunbergii [34,35], until a new genus was created and the fungus described in 1999 [25] (Table 1).

Molecular tools are crucial for the accurate identification and characterization of existing isolates and even new species. The genomic DNA of E. vermicola was successfully extracted from mycelia obtained from agar plates, liquid media and directly from pine trees. Wang et al. [36] described a simple method to extract DNA from mycelia grown in potato dextrose broth (PDB) using cetyltrimethylammonium bromide (CTAB) and later outlined a protocol for DNA extraction from agar plates [37]. A simple and effective sample preparation method was optimized by Yin et al. [38] for the DNA extraction of E. vermicola from pine trees. Briefly, it consists in dipping samples in sterile water overnight, with constant shaking, prior to using a commercially available DNA extraction kit. When this step was overlooked, performing a standard protocol did not yield enough fungal DNA to be detected by polymerase chain reaction (PCR). Genomic DNA from E. floridanum was extracted using an Extract-N-Amp Plant PCR kit with modifications [26]. Many molecular markers and their respective primer combinations have been proposed to identify Esteya to species level, but the most used is $\beta$-tubulin ( $\beta \mathrm{T})(\mathrm{Bt} 2 \mathrm{a} / \mathrm{Bt} 2 \mathrm{~b})[39,40]$. Other markers include the translation elongation factor 1- $\alpha$ (EF1- $\alpha)$ (EF1-983F and EF1-2218R) [41], the nuclear large subunit (LSU) ribosomal DNA (rDNA) (LR0R/LR5) [42,43] and the transcribed spacer regions (ITS1 and ITS2) ITS1-5.8S-ITS2 rDNA locus (ITS1F/ITS4) [44,45]. Other authors noted that ITS and LSU markers did not clearly distinguish closely-related species within the Ophiostomatales order, but were useful in assigning isolates to the species complexes or unknown lineages within Ophiostoma s. l., Leptographium s. l., and Sporothrix, whereas $\beta T$ and TEF1- $\alpha$ were robust enough to identify isolates to the species level [46]. There are currently 35 nucleotide sequences available in the National Center for Biotechnology Information taxonomy database: 27 belonging to E. vermicola, 3 to E. floridanum and 5 to unclassified Esteya spp. [47]. 
Table 1. Information on the species and isolates of Esteya currently described ( $\mathrm{T}$, type strain).

\begin{tabular}{|c|c|c|c|c|c|}
\hline Species & Strain & Origin & Year & Substrate & Reference \\
\hline \multirow{8}{*}{ E. vermicola } & CBS 156.82 & Japan & 1982 & Dried Pinus & {$[34,35]$} \\
\hline & ATCC $74485^{\mathrm{T}}$ & Taiwan & 1995 & Infected PWNs from Pinus thunbergii & [25] \\
\hline & CBS 100821 & Italy & 1998 & Twig of Olea europaea & [35] \\
\hline & CBS 115803 & Czech Republic & 1999 & Scolytus intricatus from oak tree & [48] \\
\hline & CNU 120806 & South Korea & 2006 & Infected nematodes in forest soil & {$[35]$} \\
\hline & NKF 13222 & Brazil & 2014 & $\begin{array}{c}\text { Infected Bursaphelenchus rainulfi from } \\
\text { wood packing materials }\end{array}$ & {$[37]$} \\
\hline & CXY 1893 & China & 2016 & Galleries of Tomicus yunnanensis & [49] \\
\hline & FXY 121 & China & 2021 & Pinus yunnanensis & [unpublished] \\
\hline E. floridanum & 14639 & United States & 2017 & Head of Myoplatypus flavicornis & [26] \\
\hline
\end{tabular}

Phylogenetic data have shown that Esteya, specifically E. vermicola, diverged from plant-associated Grosmannia clavigera about 135 million years ago [50], and other phylogenetic placements based on LSU sequences revealed that $E$. vermicola evolved independently to other Ophiostomatales, being closely related to the ambrosia beetle mutualist Raffaelea sulphurea [51]. There are similarities between the morphology of Esteya and Leptographium, but the nematophagous ecology of the former and the morphology of its infectious conidia are very different from other species of Leptographium s. l. Thus, it is clear that Esteya belongs in the Ophiostomatales order, but the taxonomy of this order has undergone considerable revisions in recent years and there are groupings for which monophyly is not certain, such as Leptographium s. l. (which includes Grosmannia species, the R. sulphurea species complex, and E. vermicola) [52,53]. Consequently, the status of the genus Esteya is still unresolved [52,54].

Phylogenetic analyses based on the peptide sequences of serine proteases from various entomopathogenic and nematophagous fungi revealed a closer evolutionary relationship between E. vermicola NKF 13222 and the toxin-producing fungus Clonostachys rosea, rather than with the trapping fungus Dactylellina haptotyla [55]. Further evolutionary relationships between E. vermicola strains, CBS 100821, ATCC 74485, CBS 115803 and CNU 120806, placed them in a well-supported monophyletic clade, closely related to Pseudomonas stutzeri and affiliated with Gammaproteobacteria [56]. Whole mitochondrial genome comparisons showed that E. vermicola CBS 115803 clustered together with the genus Sporothrix [32]. Interestingly, phylogenetic relationships between E. vermicola from different geographical origins showed that European isolates are in the same sub-clade, whereas the Brazilian, Korean and Taiwanese isolates are in a different sub-clade, although belonging to the same clade [49]. In relation to other Esteya species, Li et al. [26] showed that E. floridanum is phylogenetically closer to the Chinese isolate CXY 1893 of E. vermicola.

\subsection{Morphology}

Macroscopically, E. vermicola colonies (Figure 1a) appear greyish-green to dark-green and reverse dark-grey to olive-green after being cultured for 7 days on rich media $[25,37,48]$. Other authors have reported slight variations: grayish-blue with slight white on the surface and reverse dark-grey to chartreuse [35], white at first, gradually turning grayish-green and dark-green with dark-brown pigments [36,49]. In similar conditions, E. floridanum colonies (Figure $1 \mathrm{~b}$ ) appear initially white, turning light-grey after 5 days, and reverse initially white, switching to dark-brown on potato dextrose agar (PDA) and beige on malt extract agar (MEA) [26]. 


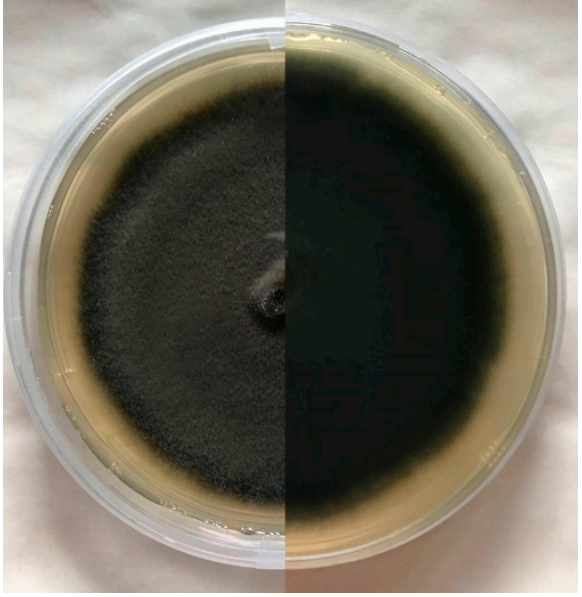

(a)

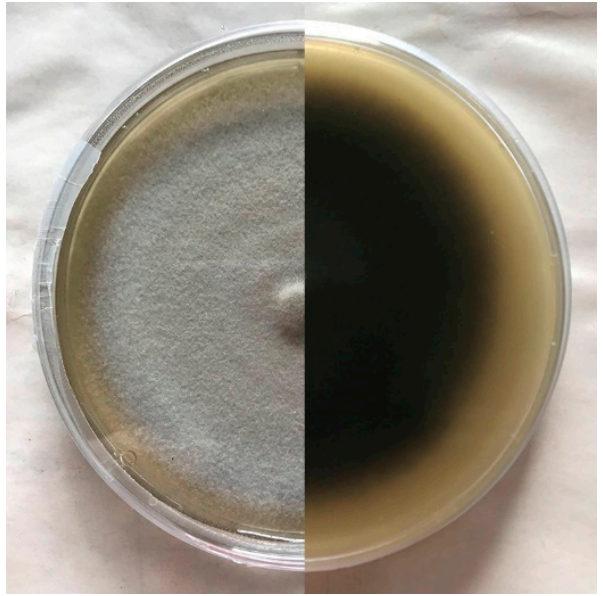

(b)

Figure 1. Upper and reverse perspectives of Esteya spp. cultured on PDA: (a) E. vermicola CNU 120806; (b) E. floridanum 14639.

Both Esteya spp. are microscopically very similar. Esteya vermicola's features include subhyaline hyphae, grey-green to olive-green, smooth to roughened, sometimes with a slime sheath. The fungus produces two types of conidiophores, conidiogenous cells and conidia, lunate and bacilloid [25,48]. Conidiogenous cells of the first type are sessile, smooth to roughened, with an olive-green inflated base, abruptly tapering into a thin subhyaline neck of varying length, often crooked and sometimes percurrent. Conidia are one-celled, lunate, subhyaline and smooth-walled, but their characteristics can vary between isolates [25,35-37,48]. For instance, ATCC 74485 and FXY121 lunate conidia are solitary, while CBS 115803, CNU 120806 and CBS 100821 can produce 1-4 spores by the same conidiogenous cell $[35,48]$. Conidiophores of the second type are loosely branched or simple, olive-green, often roughened, conidiogenous cells straight, mostly with a swollen base. Conidia cylindrical or bacilloid, one-celled, hyaline and smooth [25,48]. On the other hand, E. floridanum seems to only produce solitary lunate and bacilloid conidia, and both types of spores were observed to attach to PWNs [26]. While conidiogenous cells of E. vermicola are formed directly on the main vegetative hypae, conidiogenous cells of E. floridanum are often supported by a short, swollen cell, which connects to the main hyphae. The teleomorph of Esteya spp. was never observed.

\subsection{Distribution and Host Range}

Esteya vermicola was first isolated in Japan [35] and described in Taiwan [25]; it was later found in Italy [35], Czech Republic [48], South Korea [36], Brazil [37] and, more recently, China [49].

Esteya species were isolated from very different organisms, such as nematodes, insects and trees (Table 1). Esteya vermicola was reported to be vectored by the European oak bark beetle Scolytus intricatus [48] and Oxoplatypus quadridentatus [57]. On the other hand, E. floridanum was isolated from the ambrosia beetle Myoplatypus flavicornis [26]. An unclassified Esteya sp. was also isolated from ambrosia beetles Xylosandrus crassiusculus, Xyleborus volvulus and Xyleborinus saxesenii in Florida [58] and another unclassified Esteya sp. was obtained in Mexico from Monarthrum conversum [59], suggesting that beetles are common hosts of these fungi. Interestingly, E. vermicola can metabolize ethanol, a common trait in ambrosia beetle fungal mutualists, which could indicate that the fungus has coevolved with beetles [51]. In fact, ambrosia beetles have obligate associations with filamentous fungi $[60,61]$ and this symbiosis provides the fungi with a consistent means of dispersal [62]. In the context of PWD, Esteya spp. were never found to be associated with Monochamus. Wang et al. [36] found that E. vermicola CNU 120806 was unable to attach or infect beetle larvae of $M$. alternatus. 
The nematode host range of E. vermicola is quite vast. Apart from B. xylophilus, E. vermicola can parasitize Aphelenchoides besseyi, A. fragariae, A. ritzemabosi, B. cocophilus, B. eremus, B. mucronatus, B. rainulfi, Ditylenchus angustus, D. destructor, D. dipsaci and Panagrellus redivivus. The fungus, however, is unable to attach to and parasitize Heterodera avenae, Meloidogyne incognita and Pratylenchus penetrans [31,36,37,48].

\section{Parasitism of Esteya spp. on the PWN}

The discovery of this PWN endoparasite occurred unexpectedly, upon a survey in Taiwan, in order to prove that B. xylophilus was responsible for the death of exotic pine species [25]. After extracting nematodes from wood samples and a surface disinfection, the team attempted to culture them on a sterile mycelium on PDA. They observed a significant reduction in population density after 2-4 weeks and PWN cadavers revealed the presence of an endoparasitic hyphomycete [25].

The ability to lure motile nematode stages towards virulent spores is an important factor in successful parasitism [63]. Esteya vermicola is capable of mimicking the scent of volatile organic compounds produced by pine trees, such as $\alpha$-pinene, $\beta$-pinene and camphor, to entice PWNs for nutrients, attracting them and initiating the infective cycle [64]. However, endosymbiotic bacteria are hypothesized to be responsible for the production of these volatiles $[50,56]$ and phylogenetic analyses show that these endosymbionts are closely-related to P. stutzeri and affiliated with the class Gammaproteobacteria, being vertically transmitted from one generation to the next by sporulation [56]. Nevertheless, E. vermicola can attract PWNs from plant tissues, infected pine seedlings and even dead trees [65]. A PWN chemotaxis assay between the nematode-trapping fungus Arthrobotrys brochopaga, Botrytis cinerea and E. vermicola revealed that the latter exerted a significantly stronger attraction effect on B. xylophilus [66].

The infective cycle of E. vermicola starts when the fungus attracts the nematodes, enticing them to come into contact with the hyphae, and lunate spores adhere to the cuticle (Figure 2). These conidia usually germinate within 18-24 h, causing death when organs and tissues are completely destroyed by a mass of hyphae, growing outward and producing more lunate conidia to begin the cycle anew [67]. Esteya floridanum has a similar infection process, but only lunate conidia were observed to kill the nematode and germinate from its cadaver [26]. Lunate conidia are randomly attached throughout the nematode body, but the preferred sites appear to be the cephalic and tail regions [25], most likely due to the active movements of the head and tail, as well as the presence of chemoreceptors on the anterior part of the body [66]. Lunate spores from type strain ATCC 74485 adhered to the nematode's cuticle, whereas bacilloid conidia from this isolate were not found to infect PWNs [25]. The same was assumed for most isolates of E. vermicola, until Wang et al. [67] found bacilloid conidia in the pseudocoelom of PWNs. Moreover, E. vermicola CNU 120806 blastospores proved to be equally effective as lunate conidia in suppressing PWNs $[29,68]$. When comparing growth rate, sporulation and infectivity of four isolates of E. vermicola from two different continents, there seems to be a trade-off in Asian strains ATCC 74485 and CNU 120806 between growth rate and infectivity, while European isolates CBS 115803 and CBS 100821 grow slower but produce more lunate conidia and exhibit higher virulence towards PWNs, with the Czech strain CBS 115803 being the most promising out of the four [69].

Liou et al. [25] reported that $90 \%$ percent of inoculated PWNs were found to be infected by E. vermicola type strain within $24 \mathrm{~h}$, and almost $100 \%$ of the population was eliminated 8-10 days after inoculation. Wang et al. [36] compared the adhesion rate of E. vermicola to PWNs on different culture media and found that $90 \%$ of spores adhered to nematodes after $24 \mathrm{~h}$ on PDA, while $30 \%$ were attached to nematode cuticles on corn meal agar and only $20 \%$ on water agar. However, PWN mortality rates exceeded 90\% 10 days after inoculation on all the tested media. Wang et al. [35] compared the adhesion rates and mortality rates of two European E. vermicola isolates: CBS 115803 fared much better at suppressing PWNs, with $100 \%$ of spores attached after $12 \mathrm{~h}$ and $100 \%$ nematodes dead after just 4 days, while 
CBS 100821 featured 93\% spores attached at $24 \mathrm{~h}$ and reached a comparable mortality rate of 100\% after 10 days. In natural conditions, Wang et al. [28] assessed the ability of the fungus to suppress the PWN in P. densiflora logs and observed that nematode density decreased more than $50 \%$ in logs protected by E. vermicola CNU 120806 at the highest conidia concentration $\left(3 \times 10^{8}\right)$, compared to those inoculated with $B$. cinerea, where the nematode density increased more than $200 \%$.

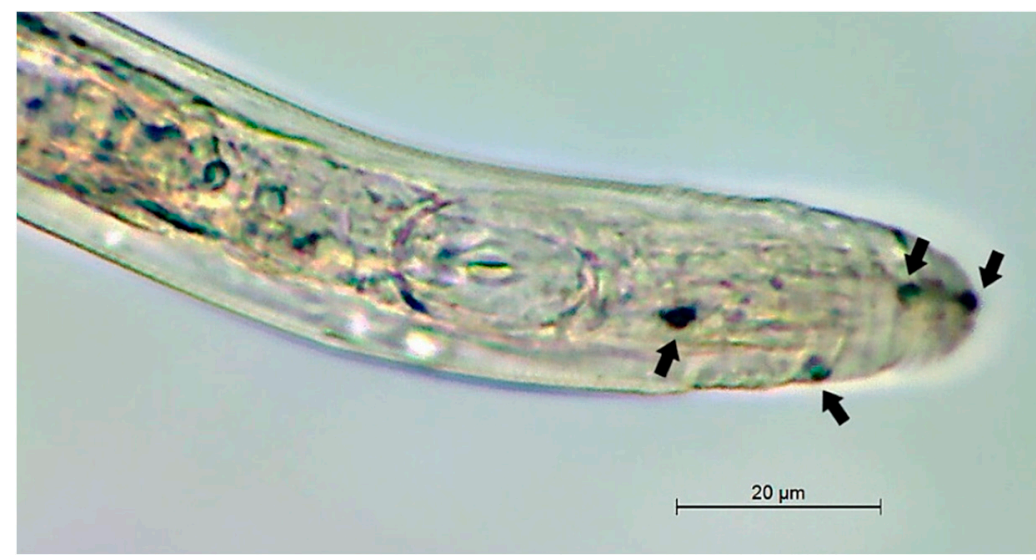

Figure 2. Cephalic region of Bursaphelenchus xylophilus, with spores of Esteya vermicola attached to the cuticle (arrows).

Recent experiments with green fluorescent protein (GFP)-tagged E. vermicola CNU 120806 revealed that this strain is capable of germinating in and colonizing pine xylem, providing evidence for the fungus' ability to infect and kill PWNs in vivo $[67,70]$. The GFP-tagged E. vermicola made it possible to better understand the infection stages: once lunate conidia adhere to PWNs, they germinate, penetrate the cuticle and induce the formation of an infection bulb in the nematode's pseudocoelom, away from the attachment site and without hyphae connecting the two fungal structures. Instead, an independent trophic hypha grows from the infection bulb, producing bacilloid conidia within the pseudocoelom, leading to a tangled mass of hyphae, reducing PWN motility and completely destroying organs and tissues from the inside out [67]. This suggests that $E$. vermicola can be further dispersed by infected nematodes as they migrate within their host, attracting more PWNs and initiating new infection cycles elsewhere, which are usually completed within 4 days $[67,68,70]$. Esteya floridanum, however, only seems to be capable of delaying tree death, as reported by Li et al. [26], who noticed that larch (Larix olgensis) and Korean pines (P. koraiensis) died a few weeks later compared to positive controls, when inoculated with the fungus prior to PWN infection. Nevertheless, the fungus was only tested on pine seedlings, which are usually more susceptible to pathogens and pests [71]. Esteya floridanum is an endophyte of pine trees [26].

De novo assembly yielded a genome of $34.2 \mathrm{Mb}$ in length, with average $68.59 \times$ coverage depth. Combined de novo and homology prediction produced 8427 proteincoding genes. Further annotation results of E. vermicola genome revealed that there were no $\alpha$ - and $\beta$-pinene monoterpenoid synthase-encoding genes, suggesting that endosymbiotic bacteria might be responsible for the production of monoterpenes that attract PWNs $[50,56]$. Insights into the genome of $E$. vermicola revealed highly expanded endo- $\beta$-glucanase gene families, which were identified as parasitism genes in plant-parasitic nematode [72]. These enzymes likely play a crucial role in their pathogenicity, by degrading glucans from nematodes they infect [50]. Similar enzymes are also found in PWNs and since $\beta-1,3$-glucan is the main structural component of fungal cell walls, it seems probable that $\beta$-1,3-glucanases may play an important role in their mycophagous phase [73]. 


\section{Application of Esteya spp. for a Sustainable PWD Management}

\subsection{Culturing}

Nutrients exert an influence on the growth and sporulation rates of different strains of E. vermicola. Most isolates grow faster on nutrient-rich media. Likewise, the proportion of lunate and bacilloid conidia are linked to the availability of nutrients in the medium. CNU 120806 produces more lunate conidia in nutrient-rich media [48], whereas a negative correlation exists between adhesive conidia from ATCC 74485 and NKF 13222 and nutrients $[25,36,37]$. The most efficient medium to multiply blastospores of E. vermicola CBS 115803 was shown to be PDB, supplemented with wheat bran and pine powder [74]. When nitrogen sources (glycine and t-leucine) were added to PDA as supplements, the fungus growth rate increased [75]. These two nitrogen sources also stimulated the production of lunate spores, exerting a significant influence on the adhesive and mortality rates against $B$. xylophilus and enhancing the survival rate of the fungus during abiotic stress [75]. Some mineral salts produce similar effects: $\mathrm{CaCl}_{2}$ and $\mathrm{CaCO}_{3}$ were effective in enhancing growth rate, sporulation and virulence of E. vermicola [76]. Carbon sources also seem to play a crucial role in the mechanisms of Esteya parasitism, which are yet to be clearly understood. For instance, easily metabolized carbon sources, such as glucose, were shown to result in the repression of various fungal genes needed to metabolize other carbon sources in the nematophagous fungus Pochonia chlamydosporia [77]. On the other hand, E. vermicola features more carbon transporters compared to many nematophagous fungi [50]. Remarkably, the proportion of expanded gene families of transporters in E. vermicola is much higher than that of other analyzed species of nematophagous fungi [50]. The transporters of expanded gene families in E. vermicola occurred mainly for carbon source, nitrogen source, iron and vitamin transport, which provide the basis for effectively absorbing nutrients from nematodes [50].

The optimal growth conditions for Esteya spp. are $26{ }^{\circ} \mathrm{C}$ and rich media, such as MEA and PDA. In these conditions, E. vermicola CNU 120806 reached about $4.0-4.5 \mathrm{~cm}$ in diameter after 8 days [36], CBS $1158033.0-3.7 \mathrm{~cm}$ [48] and ATCC $744853.0-4.5 \mathrm{~cm}$ [25]. Wang et al. [75] reported that the same isolate grew to a diameter of $2.50 \pm 0.17 \mathrm{~cm}(p<0.05)$ over the same period and at the same temperature. By contrast, CBS 100821 grew slowly on PDA, reaching 2.7-3.0 cm in diameter, in the aforementioned conditions [35]. Colonies of the isolate CBS 115803 were 26-32 mm in diameter after being cultured on 2\% MEA for 7 days at $25{ }^{\circ} \mathrm{C}$ [48]. Esteya floridanum reared on PDA grew an average of $2.73 \pm 0.68 \mathrm{~mm}$ and $3.33 \pm 0.33 \mathrm{~mm}$ per day, at $25^{\circ} \mathrm{C}$ and $30^{\circ} \mathrm{C}$, respectively [26].

\subsection{Mass Production and Maintenance}

Mass production, stress tolerance, storage time and application of biocontrol agents are all important factors when considering biocontrol strategies, but they can be very challenging. Esteya vermicola mostly produces blastospores in liquid media and aerial conidia (lunate and bacilloid) on solid media [31]. Thus, blastospores can easily be multiplied in liquid medium [74], while a two-phase culture method is needed for aerial conidia production [74,78,79]. Wang et al. [75] tested the effect of mineral salts on the growth rate, sporulation and virulence of E. vermicola $\mathrm{CNU} 120806$ and found that $\mathrm{CaCl}_{2}$ not only boosted the growth rate and sporulation of the fungus, but also produced the highest adhesive rate and mortality against the PWN. Wang et al. [76] observed that spores of E. vermicola CNU 120806 produced in media supplemented with glycine and t-leucine had slightly higher ultraviolet (UV) and drought resistance than spores produced without nitrogen sources. Wang et al. [80] assessed the protective properties of different compounds on the conidial resistance of E. vermicola CBS 115803 to environmental stressors, with a formulation of $0.2 \%$ fulvic acid and $4 \%$ skimmed milk, $5 \%$ sorbitol and $0.05 \% \mathrm{CaCl}_{2}$ protecting against UV, drought and heat stress, respectively. Xue et al. [81] found that applying herbal extracts to PDA enhanced tolerance to abiotic stress, such as drought, heat and UV radiation, in E. vermicola CBS 115803, CBS 100821 and CNU 120806. Wang et al. [74] noted that blastospores of E. vermicola CBS 115803 produced in liquid-state fermentation fared 
better in terms of yield and PWN mortality rate, but their germination, storage life and stress tolerance were worse when compared to aerial conidia. Xue et al. [78] showed that hydrogen peroxide promotes the sporulation of E. vermicola CBS 115803 conidia, under specific conditions, without them losing viability. Wang et al. [70] optimized a cost-effective formula to protect spores of E. vermicola CBS 115803, containing $69.9 \%$ soluble starch, $14 \%$ wheat flour, 5\% PEG8000, 0.1\% Span 80, 1\% arabinose and 10\% skimmed milk, yielding almost $80 \%$ germination rates under desiccation stress. Although lunate conidia are significantly more resistant to stress [74], Yin et al. [68] deduced that abiotic stress can be mitigated by directly injecting blastospores into pine trees. Zhu et al. [79] developed a low-cost solid-state fermentation (SSF) method for mass production of aerial conidia, using rice as a carrier to absorb the conidial suspension of E. vermicola CBS 115803. This study provides the basis for an economical high-quality conidia production system, without the need for additional nutrients such as carbon and nitrogen sources. While other production systems are more efficient, SSF is preferred for field application [82-85].

\subsection{Implications for Field Use and Biocontrol Strategies}

If biological control strategies are to be successful, the most efficient inoculation methods should be used for maximum effect. Wang et al. [28] observed that spraying a conidial suspension of E. vermicola CNU 120806 on four-year-old pine seedlings of P. densiflora resulted in a delay of plant death but did not prevent PWD. Nevertheless, PWN density was significantly higher in seedlings without the protective effect of E. vermicola. Likewise, Wang et al. [22] also reported improvements in the survival rate of P. densiflora seedlings against the PWN by spraying them with an E. vermicola CNU 120806 conidial suspension before nematode infection, which increased proportionally with colony-forming units (CFU) per $\mathrm{mL}$, although the time interval between spraying pine seedlings with E. vermicola and PWN infection produced different effects on the survival rate: a 20 day interval between spraying and infection significantly differed from the survival rate of seedlings at 10 and 30 day intervals. In a field experiment, Wang et al. [29] inoculated 15-30 year-old P. densiflora with three different treatments: $2 \mathrm{~mL}$ of a $40 \%$ Esteya-infected PWN suspension (approximately 30,000 individuals, 12,000 of which were infected by the fungus), 30-40 mL of either a liquid culture or solid culture substrate of E. vermicola CNU 120806 and $2 \mathrm{~mL}$ of $40 \%$ Esteya-infected PWN suspension, 110 days prior to a regular PWN inoculation ( $1 \mathrm{~mL}$, approximately 10,000 individuals), with 10 trees per treatment. In the first treatment, the tree survival rate was $80 \%$ during the months following the beginning of the experiment, decreasing to $60 \%$ within a year and stabilizing at $50 \%$ over a 3-year period. When the trees were preemptively treated with a liquid culture of $E$. vermicola, the tree survival rate was $60 \%$ during the first year, dropping to $30 \%$ the over next 12 months and remaining there for a further 4 years. On the other hand, the survival rate of pines treated with the solid substrate of E. vermicola started at $80 \%$, dropping to $40 \%$ two years later and remaining there over a 4-year period [29]. The same authors also tested the effect of the fungus using a different method: in total, 10 P. densiflora were artificially infected with the aforementioned PWN suspension and, a week later, trees were injected with $2 \mathrm{~mL}$ of an 80\% Esteya-infected PWN suspension (approximately 30,000 individuals, 24,000 of which were infected by lunate conidia of E. vermicola). Six trees died within 12 months, and the survival rate remained at $40 \%$ over the six-year experiment [29]. A statistical analysis showed that the protective effect of E. vermicola was significantly higher $(p<0.05)$ than the remedial effect of the fungus only when trees were treated with $40 \%$ infected PWN suspensions [29]. Another field experiment conducted by Yin et al. [68] demonstrated the potential of E. vermicola. Here, 40 healthy 15-20 year-old P. thunbergii were randomly divided into three groups: prevention group (15 trees pre-injected with E. vermicola CNU 120806 one month before PWN inoculation), cure group (15 trees injected with E. vermicola two and four weeks after PWN infection) and control group (10 trees inoculated with PWNs only). In the prevention group, the survival rate of these pine trees was over $70 \%$, significantly higher than that of the cure group (40\%). Wang et al. [70] carried out a field 
trial that provides evidence for a promising field application of E. vermicola. Eighty healthy 10 year-old $P$. densiflora were selected and randomly divided into four groups (prevention group, cure group, positive control and negative control), with twenty trees per group. Trees in the prevention group were inoculated with $10 \mathrm{~mL}$ of E. vermicola CNU 120806 conidial suspension by trunk injection through drilled holes and, one month later, the PWN was inoculated. The trees in the cure group were infected with PWNs two weeks before the injection of E. vermicola conidial suspension. The trees in the positive and negative control groups were inoculated with PWNs and sterile distilled water, respectively. The survival rates of the tested trees in the prevention and cure groups were $90 \%$ and $80 \%$, respectively, much higher than that of the positive control group (50\%). Expectedly, nematode density in wilted trees from the positive control group (2024.6 $\pm 146.8 / \mathrm{g}$ wood) was significantly higher than that observed in the prevention $(301.5 \pm 33.5 / \mathrm{g}$ wood) and cure $(494 \pm 117.38 / \mathrm{g}$ wood $)$ treatments $(p<0.001)$. An assay in controlled conditions was performed by Li et al. [26] to assess the protective effect of E. floridanum. Twenty seedlings of $P$. koraiensis were preemptively inoculated with $1 \mathrm{~mL}$ of spores suspension of E. floridanum (approximately $10^{6}$ spores) and another twenty seedlings were left untreated. Two weeks later, all 40 plants were inoculated with a PWN suspension (approximately 1,000 nematodes per seedling). All the seedlings died after 14 weeks and $75 \%$ of Korean pine seedlings wilted 2 weeks after PWN inoculation. In plants treated with E. floridanum, wilting symptoms and death were deferred for 2-4 weeks and 4-6 weeks, respectively. In contrast, untreated seedlings died within 8 weeks post-PWN inoculation, whereas only $35 \%$ of Korean pines previously injected with the fungus died within that timeframe.

\section{Future Perspectives}

In over twenty years, only two Esteya spp. were discovered and eight isolates of E. vermicola described, but more possibly exist. Considering their ubiquitous nature, isolated from varying substrates and often associated with ambrosia and bark beetles, bioprospecting new Esteya spp. or isolates should focus heavily on those insects. Moreover, the status of the genus Esteya remains unresolved.

The possible role of endosymbiotic bacteria, living inside $E$. vermicola, in their parasitic lifestyle should be key areas of focus. Likewise, potential endosymbionts of E. floridanum are still unexplored.

Technology is ever evolving and omics are fundamental tools to elucidate important mechanisms and metabolic pathways involved in the parasitism and pathogenicity of these fungi. A knowledge gap still prevails in the complex trophic interactions between Esteya, PWNs and Pinus hosts. The use of omics to characterize Esteya spp. is currently very limited. High-throughput sequencing technologies, such as transcriptomics of Esteya during its interaction with the PWN, would provide new insights into the parasitic mechanisms of existing isolates and species.

Author Contributions: Conceptualization, D.P. and C.S.L.V.; writing—original draft preparation, D.P.; writing—review and editing, C.S.L.V., M.L.I. and M.M.; supervision, M.L.I., C.S.L.V. and M.M.; project administration, M.L.I.; funding acquisition, M.L.I. All authors have read and agreed to the published version of the manuscript.

Funding: This work is funded by the Portuguese Foundation for Science and Technology (Fundação para a Ciência e a Tecnologia-FCT), namely: PhD Fellowship 2021.08030.BD (D.P.) and the national project "PineENEMY - Exploring the NEmatode-MYcobiota interactions in Pine Wilt Disease" (LISBOA-01-0145-FEDER-028724).

Acknowledgments: The authors sincerely thank Bryan Sung (DBio, Inc.) and You Li (University of Florida) for providing the Esteya isolates, the PineENEMY project team and the staff at the laboratories of Nematology at INIAV (NemaINIAV, INIAV, I.P.) and University of Évora/MED (NemaLab).

Conflicts of Interest: The authors declare no conflict of interest. The funders had no role in the design of the study; in the collection, analyses, or interpretation of data; in the writing of the manuscript, or in the decision to publish the results. 


\section{References}

1. EPPO Global Database. Available online: https://gd.eppo.int/taxon/BURSXY/categorization (accessed on 18 November 2021).

2. Evans, H.; McNamara, D.; Braasch, H.; Chadouef, J.; Magnusson, C. Pest risk analysis (PRA) for the territories of the European Union (as PRA area) on Bursaphelenchus xylophilus and its vectors in the genus Monochamus. EPPO Bull. 1996, $26,199-249$. [CrossRef]

3. Futai, K. Pine wood nematode, Bursaphelenchus xylophilus. Annu. Rev. Phytopathol. 2013, 51, 61-83. [CrossRef]

4. Jones, J.T.; Haegeman, A.; Danchin, E.G.J.; Gaur, H.S.; Helder, J.; Jones, M.G.K.; Kikuchi, T.; Manzanilla-López, R.; Palomares-Rius, J.E.; Wesemael, W.M.L.; et al. Top 10 plant-parasitic nematodes in molecular plant pathology. Mol. Plant Pathol. 2013, 14, 946-961. [CrossRef] [PubMed]

5. Mamiya, Y. Pathology of the pine wilt disease caused by Bursaphelenchus xylophilus. Annu. Rev. Phytopathol. 1983, 21, 201-220. [CrossRef]

6. Zhao, B.G.; Futai, K.; Sutherland, J.R.; Takeuchi, Y. Pine Wilt Disease; Springer: Tokyo, Japan, 2008.

7. Naves, P.; Bonifácio, L.; Sousa, E. Nematode-Vector. In Pine Wilt Disease in Europe: Biological Interactions and Integrated Management, 1st ed.; Sousa, E., Vale, F., Abrantes, I., Eds.; FNAPF-Federação Nacional das Associações de Proprietários Florestais: Lisbon, Portugal, 2015; pp. 81-122.

8. Schenk, M.; Loomans, A.; den Nijs, L.; Hoppe, B.; Kinkar, M.; Vos, S. Pest Survey Card on Bursaphelenchus xylophilus; EFSA Supporting Publication; EFSA: Parma, Italy, 2020; EN-1782, pp. 1-32. [CrossRef]

9. Jones, J.T.; Moens, M.; Mota, M.; Li, H.; Kikuchi, T. Bursaphelenchus xylophilus: Opportunities in comparative genomics and molecular host-parasite interactions. Mol. Plant Pathol. 2008, 9, 357-368. [CrossRef] [PubMed]

10. Tokushige, Y.; Kiyohara, T. Bursaphelenchus sp. in the wood of dead pine trees. J. Jap. For. Soc. 1969, 51, 193-195. [CrossRef]

11. Kiyohara, T.; Tokushige, Y. Inoculation experiments of a nematode, Bursaphelenchus sp., onto pine trees. J. Jap. For. Soc. 1971, 53, 210-218. [CrossRef]

12. Sousa, E.; Vale, F.; Abrantes, I. Pine Wilt Disease in Europe: Biological Interactions and Integrated Management, 1st ed.; FNAPFFederação Nacional das Associações de Proprietários Florestais: Lisbon, Portugal, 2015; pp. 35-84.

13. Robinet, C.; Castagnone-Sereno, P.; Mota, M.; Roux, G.; Sarniguet, C.; Tassus, X.; Jactel, H. Effectiveness of clear-cuttings in non-fragmented pine forests in relation to EU regulations for the eradication of the pine wood nematode. J. Appl. Ecol. 2019, 57, 460-466. [CrossRef]

14. Carnegie, A.J.; Venn, T.; Lawson, S.; Nagel, M.; Wardlaw, T.; Cameron, N.; Last, I. An analysis of pest risk and potential economic impact of pine wilt disease to Pinus plantations in Australia. Aust. For. 2018, 81, 24-36. [CrossRef]

15. Soliman, T.; Mourits, M.C.; van der Werf, W.; Hengeveld, G.M.; Robinet, C.; Lansink, A.G. Framework for modelling economic impacts of invasive species, applied to pine wood nematode in Europe. PLoS ONE 2012, 7, e45505. [CrossRef] [PubMed]

16. Webster, J.; Mota, M. Global issues, trade and economic impact. In Pine Wilt Disease: A Worldwide Threat to Forest Ecosystems, 1st ed.; Mota, M., Vieira, P., Eds.; Springer: Dordrecht, The Netherlands, 2008; pp. 1-4.

17. Kiyohara, T.; Bolla, R.I. Pathogenic variability among populations of the pinewood nematode, Bursaphelenchus xylophilus. For. Sci. 1990, 36, 1061-1076. [CrossRef]

18. Suzuki, K. Pine wilt disease-A threat to pine forest in Europe. Dendrobiology 2002, 48, 71-74.

19. An, H.; Lee, S.; Cho, S.J. The effects of climate change on pine wilt disease in South Korea: Challenges and prospects. Forests 2019, 10, 486. [CrossRef]

20. Hirata, A.; Nakamura, K.; Nakao, K.; Kominami, Y.; Tanaka, N.; Ohashi, H.; Takano, K.T.; Takeuchi, W.; Matsui, T. Potential distribution of pine wilt disease under future climate change scenarios. PLoS ONE 2017, 12, e0182837. [CrossRef] [PubMed]

21. Tang, X.; Yuan, Y.; Li, X.; Zhang, J. Maximum entropy modeling to predict the impact of climate change on pine wilt disease in China. Front. Plant Sci. 2021, 12, 652500. [CrossRef] [PubMed]

22. Wang, Z.; Zhang, Y.; Wang, C.; Wang, Y.; Sung, C. Esteya vermicola controls the pinewood nematode, Bursaphelenchus xylophilus, in pine seedlings. J. Nematol. 2017, 49, 86-91. [CrossRef] [PubMed]

23. Wang, Z.; Wang, C.Y.; Yang, Z.; Fang, Z.; Moon, Y.; Sun, B.; Lee, M.R.; Sung, C. Viability and pathogenicity of Esteya vermicola in pine trees. Biocontrol Sci. Technol. 2011, 21, 387-393. [CrossRef]

24. Vicente, C.S.L.; Soares, M.; Faria, J.M.S.; Ramos, A.P.; Inácio, M.L. Insights into the role of fungi in pine wilt disease. J. Fungi 2021, 7, 780. [CrossRef] [PubMed]

25. Liou, J.Y.; Shih, J.Y.; Tzean, S.S. Esteya, a new nematophagous genus from Taiwan, attacking the pinewood nematode (Bursaphelenchus xylophilus). Mycol. Res. 1999, 103, 242-248. [CrossRef]

26. Li, Y.; Yu, H.; Araújo, J.; Zhang, X.; Ji, Y.; Hulcr, J. Esteya floridanum sp. nov.: An Ophiostomatalean nematophagous fungus and its potential to control the pine wood nematode. Phytopathology 2021, 111, 304-311. [CrossRef]

27. Chu, W.H.; Dou, Q.; Chu, H.; Wang, H.H.; Sung, C.; Wang, C. Research advance on Esteya vermicola, a high potential biocontrol agent of pine wilt disease. Mycol. Prog. 2015, 14, 115. [CrossRef]

28. Wang, C.Y.; Fang, Z.M.; Wang, Z.; Zhang, D.L.; Gu, L.J.; Lee, M.R.; Liu, L.; Sung, C.K. Biological control of the pinewood nematode Bursaphelenchus xylophilus by application of the endoparasitic fungus Esteya vermicola. BioControl 2010, 56, 91-100. [CrossRef]

29. Wang, C.Y.; Yin, C.; Fang, Z.M.; Wang, Z.; Wang, Y.B.; Xue, J.J.; Gu, L.J.; Sung, C.K. Using the nematophagous fungus Esteya vermicola to control the disastrous pine wilt disease. Biocontrol. Sci. Technol. 2018, 28, 268-277. [CrossRef] 
30. Fang, Z.M.; Wang, C.Y.; Wang, Z.; Gu, L.J.; Lee, Q.H.; Lee, M.R.; Sung, C.K. A Biocontrol Agent of Pinewood Nematode and Application Method. South. Korea Patent 10-1033270, 21 June 2010.

31. Tzean, S.S.; Liou, J.Y.; Shih, J.Y. Nematophagous fungus Esteya vermicola. U.S. Patent 006168947B1, 2 January 2001.

32. Wang, R.; Dong, L.; Chen, Y.; Qu, L.; Li, E.; Wang, Q.; Zhang, Y. The complete mitochondrial genome of nematophagous fungus Esteya vermicola. Mitochondrial DNA B: Resour. 2017, 2, 196-197. [CrossRef] [PubMed]

33. Kim, J.J.; Lim, Y.W.; Breull, C.; Wingfield, M.J.; Zhou, X.D.; Kim, G.H. A new Leptographium species associated with Tomicus piniperda infesting pine logs in Korea. Mycol. Res. 2005, 109, 275-284. [CrossRef]

34. Westerdijk Fungal Biodiversity Institute. Available online: https://wi.knaw.nl/page/fungal_display/28844 (accessed on 14 December 2021).

35. Wang, C.Y.; Fang, Z.M.; Wang, Z.; Gu, L.J.; Sun, B.S.; Zhang, D.L.; Sung, C.K. High infection activities of two Esteya vermicola isolates against pinewood nematode. Afr. J. Microbiol. Res. 2009, 3, 581-584. [CrossRef]

36. Wang, C.Y.; Fang, Z.M.; Sun, B.S.; Gu, L.J.; Zhang, K.Q.; Sung, C.K. High infectivity of an endoparasitic fungus strain, Esteya vermicola, against nematodes. J. Microbiol. 2008, 46, 380-389. [CrossRef] [PubMed]

37. Wang, X.; Wang, T.T.; Wang, J.C.; Guan, T.L.; Li, H.M. Morphological, molecular and biological characterization of Esteya vermicola, a nematophagous fungus isolated from intercepted wood packing materials exported from Brazil. Mycoscience 2014, 55, 367-377. [CrossRef]

38. Yin, C.; Wang, Y.; Zhang, Y.; Wang, H.; Tao, R.; Li, Y.; Sung, C.K. A pine wood sample preparation method for high target and quality DNA extraction for detection of Esteya vermicola by PCR from living pine. J. Basic Microbiol. 2019, 59, 437-441. [CrossRef]

39. Glass, N.L.; Donaldson, G.C. Development of primer sets designed for use with the PCR to amplify conserved genes from filamentous ascomycetes. Appl. Environ. Microbiol. 1995, 61, 1323-1330. [CrossRef]

40. O'Donnell, K.; Cigelnik, E. Two divergent intragenomic rDNA ITS2 types within a monophyletic lineage of the fungus Fusarium are nonorthologous. Mol. Phylogenet. Evol. 1997, 7, 103-116. [CrossRef] [PubMed]

41. Rehner, S.A.; Buckley, E. A Beauveria phylogeny inferred from nuclear ITS and EF1- $\alpha$ sequences: Evidence for cryptic diversification and links to Cordyceps teleomorphs. Mycologia 2005, 97, 84-98. [CrossRef]

42. Hopple, J.S., Jr. Phylogenetic Investigations in the Genus Coprinus Based on Morphological and Molecular Characters. Ph.D. Thesis, Duke University, Durham, NC, USA, 1994.

43. Vilgalys, R.; Hester, M. Rapid genetic identification and mapping of enzymatically amplified ribosomal DNA from several Cryptococcus species. J. Bacteriol. 1990, 172, 4238-4246. [CrossRef] [PubMed]

44. Gardes, M.; Bruns, T.D. ITS Primers with enhanced specificity for Basidiomycetes-Application to the identification of mycorrhizae and rusts. Mol. Ecol. 1993, 2, 113-118. [CrossRef]

45. White, T.J.; Bruns, T.D.; Lee, S.B.; Taylor, J.W. Amplification and direct sequencing of fungal ribosomal RNA genes for phylogenetics. In PCR Protocols: A Guide to Methods and Applications; Innis, M.A., Gelfand, D.H., Sninsky, J.J., White, T.J., Eds.; Academic Press: Cambridge, MA, USA, 1990; Volume 18, pp. 315-322.

46. Jankowiak, R.; Strzałka, B.; Bilański, P.; Kacprzyk, M.; Wieczorek, P.; Linnakoski, R. Ophiostomatoid fungi associated with hardwood-infesting bark and ambrosia beetles in Poland: Taxonomic diversity and vector specificity. Fungal Ecol. 2019, 39, 152-167. [CrossRef]

47. National Center for Biotechnology Information Taxonomy Database. Available online: https://www.ncbi.nlm.nih.gov/ Taxonomy/Browser / wwwtax.cgi?id=522481 (accessed on 14 December 2021).

48. Kubátová, A.; Novotný, D.; Prášil, K.; Mráček, Z. The nematophagous hyphomycete Esteya vermicola found in the Czech Republic. Czech Mycol. 2000, 52, 227-235. [CrossRef]

49. Wang, H.M.; Wang, Z.; Liu, F.; Wu, C.X.; Zhang, S.F.; Kong, X.B.; Decock, C.; Lu, Q.; Zhang, Z. Differential patterns of ophiostomatoid fungal communities associated with three sympatric Tomicus species infesting pines in south-western China, with a description of four new species. MycoKeys 2019, 50, 93-133. [CrossRef]

50. Wang, R.; Dong, L.; He, R.; Wang, Q.; Chen, Y.; Qu, L.; Zhang, Y.A. Comparative genomic analyses reveal the features for adaptation to nematodes in fungi. DNA Res. 2018, 25, 245-256. [CrossRef] [PubMed]

51. Lehenberger, M.; Benkert, M.; Biedermann, P.H.W. Ethanol-enriched substrate facilitates ambrosia beetle fungi, but inhibits their pathogens and fungal symbionts of bark beetles. Front. Microbiol. 2021, 11, 590111. [CrossRef]

52. De Beer, Z.W.; Duong, T.A.; Wingfield, M.J. The divorce of Sporothrix and Ophiostoma: Solution to a problematic relationship. Stud. Mycol. 2016, 83, 165-191. [CrossRef] [PubMed]

53. Zubaer, A.; Wai, A.; Patel, N.; Perillo, J.; Hausner, G. The mitogenomes of Ophiostoma minus and Ophiostoma piliferum and comparisons with other members of the Ophiostomatales. Front. Microbiol. 2021, 12, 618649. [CrossRef] [PubMed]

54. De Beer, Z.W.; Wingfield, M.J. Emerging lineages in the Ophiostomatales. In Ophiostomatoid fungi: Expanding Frontiers; Seifert, K.A., De Beer, Z.W., Wingfield, M.J., Eds.; Series 12; CBS-KNAW Biodiversity: Utrecht, The Netherlands, 2013 ; pp. $21-46$.

55. Wang, X.; Guan, T.; Zhang, L.; Li, H. Cloning of a serine protease gene from the nematophagous fungus Esteya vermicola and expressed activity of the recombinant enzyme against Bursaphelenchus xylophilus. Nematology 2015, 17, 1071-1080. [CrossRef]

56. Wang, R.; Dong, L.; Chen, Y.; Qu, L.; Wang, Q.; Zhang, Y. Esteya vermicola, a nematophagous fungus attacking the pine wood nematode, harbors a bacterial endosymbiont affiliated with Gammaproteobacteria. Microbes Environ. 2017, 32, 201-209. [CrossRef] 
57. Li, Y.; Huang, Y.T.; Kasson, M.T.; Macias, A.M.; Skelton, J.; Carlson, P.S.; Yin, M.; Hulcr, J. Specific and promiscuous ophiostomatalean fungi associated with Platypodinae ambrosia beetles in the southeastern United States. Fungal Ecol. 2018, 35, 42-50. [CrossRef]

58. Cruz, L.F.; Menocal, O.; Kendra, P.E.; Carrillo, D. Phoretic and internal transport of Raffaelea lauricola by different species of ambrosia beetle associated with avocado trees. Symbiosis 2021, 84, 151-161. [CrossRef]

59. Restrepo, M.A. Escarabajos Ambrosiales y Sus Hongos Simbiontes Asociados al Cultivo de Aguacate "Hass" en Michoacán. Master's Thesis, Universidad Michoacana de San Nicolás de Hidalgo, Morelia, Mexico, 2019.

60. Jordal, B.H. Molecular phylogeny and biogeography of the weevil subfamily Platypodinae reveals evolutionarily conserved range patterns. Mol. Phylogenet. Evol. 2015, 92, 294-307. [CrossRef] [PubMed]

61. Six, D.L. Ecological and evolutionary determinants of bark beetle-Fungus symbioses. Insects 2012, 3, 339-366. [CrossRef]

62. Inácio, M.L.; Marcelino, J.; Lima, A.; Sousa, E.; Nóbrega, F. Raffaelea quercina sp. nov. associated with cork oak (Quercus suber L.) decline in Portugal. Forests 2021, 12, 513. [CrossRef]

63. Zhang, K.Q.; Hyde, K.D. Nematode-Trapping Fungi; Springer: Dordrecht, The Netherlands, 2014.

64. Lin, F.; Ye, J.L.; Wang, H.G.; Zhang, A.J.; Zhao, B.G. Host deception: Predaceous fungus, Esteya vermicola, entices pine wood nematode by mimicking the scent of pine tree for nutrient. PLoS ONE 2013, 8, e71676. [CrossRef]

65. Wang, C.Y.; Wang, Z.; Lee, M.L.; Li, Z.; Zhang, D.L.; Liu, L.; Fang, Z.M.; Sung, C.K. Attraction of pinewood nematode, Bursaphelenchus xylophilus, to the endoparasitic fungus Esteya vermicola. Afr. J. Microbiol. Res. 2009, 3, 782-786. [CrossRef]

66. Wang, C.Y.; Wang, Z.; Fang, Z.M.; Zhang, D.L.; Gu, L.J.; Liu, L.; Sung, C.K. Attraction of pinewood nematode to endoparasitic nematophagous fungus Esteya vermicola. Curr. Microbiol. 2010, 60, 387-392. [CrossRef]

67. Wang, H.H.; Wang, Y.B.; Yin, C.; Gao, J.; Tao, R.; Sun, Y.L.; Wang, C.Y.; Wang, Z.; Li, Y.X.; Sung, C.K. In vivo infection of Bursaphelenchus xylophilus by the fungus Esteya vermicola. Pest Manag. Sci. 2020, 76, 2854-2864. [CrossRef]

68. Yin, C.; Wang, Y.; Zhang, Y.; Wang, H.; Duan, B.; Tao, R.; Gao, J.; Sung, C.K. Hypothesized mechanism of biocontrol against pine wilt disease by the nematophagous fungus Esteya vermicola. Eur. J. Plant Pathol. 2020, 156, 811-818. [CrossRef]

69. Wang, H.; Chu, H.; Xie, Q.; Dou, Q.; Feng, H.; Yang, C.; Wang, C. Variation in sporulation of four Esteya vermicola isolates and their infectivity against pinewood nematode. Sci. Silvae Sin. 2016, 52, 139-146.

70. Wang, H.H.; Yin, C.; Tao, R.; Gao, J.; Sun, Y.L.; Cho, J.H.; Wang, Z.; Wang, Y.B.; Wang, C.Y.; Sung, C.K. Migration of pinewood nematode promotes the colonization of Esteya vermicola in pine tree. For. Pathol. 2021, 51, e12668. [CrossRef]

71. Rabiey, M.; Hailey, L.E.; Roy, S.R.; Grenz, K.; Al-Zadjali, M.A.; Barrett, G.A.; Jackson, R.W. Endophytes vs. tree pathogens and pests: Can they be used as biological control agents to improve tree health? Eur. J. Plant Pathol. 2019, 155, 711-729. [CrossRef]

72. Berg, R.H.; Fester, T.; Taylor, C.G. Cell Biology of Plant Nematode Parasitism. In Plant Cell Monographs; Berg, R.H., Taylor, C.G., Eds.; Springer: Berlin/Heidelberg, Germany, 2009; Volume 15, pp. 115-152.

73. Kikuchi, T.; Shibuya, H.; Jones, J.T. Molecular and biochemical characterization of an endo-beta-1,3-glucanase from the pinewood nematode Bursaphelenchus xylophilus acquired by horizontal gene transfer from bacteria. Biochem. J. 2005, 389, 117-125. [CrossRef]

74. Wang, Y.B.; Yang, Z.H.; Yu, J.J.; Zhang, Y.A.; Xue, J.J.; Li, Z.; Li, J.J.; Wang, C.Y.; Wang, Z.; Hou, J.G.; et al. Comparison between conidia and blastospores of Esteya vermicola, an endoparasitic fungus of the pinewood nematode, Bursaphelenchus xylophilus World J. Microbiol. Biotechnol. 2013, 29, 2429-2436. [CrossRef]

75. Wang, Z.; Wang, C.Y.; Gu, L.J.; Wang, Y.B.; Zhang, Y.A.; Sung, C.K. Growth of Esteya vermicola in media amended with nitrogen sources yields conidia with increased predacity and resistance to environmental stress. Can. J. Microbiol. 2011, 57, 838-843. [CrossRef]

76. Wang, Z.; Wang, C.; Liu, M.; Zhang, Y.; Xue, J.; Wang, Y.; Li, Z.; Hou, Z.; Li, J.; Sung, C. Effects of mineral salts on the growth, sporulation and virulence of Esteya vermicola, an endoparasitic fungus of the pinewood nematode, Bursaphelenchus xylophilus. Biocontrol Sci. Technol. 2011, 21, 1485-1493. [CrossRef]

77. Ward, E.; Kerry, B.R.; Manzanilla-López, R.H.; Mutua, G.; Devonshire, J.; Kimenju, J.; Hirsch, P.R. The Pochonia chlamydosporia serine protease gene $v c p 1$ is subject to regulation by carbon, nitrogen and $\mathrm{pH}$ : Implications for nematode biocontrol. PLoS ONE 2012, 7, e35657. [CrossRef]

78. Xue, J.; Hou, J.; Zhang, Y.; Wang, Y.; Lee, M.; Yu, J.; Sung, C. Optimization of promoting conidial production of a pinewood nematode biocontrol fungus, Esteya vermicola using response surface methodology. Curr. Microbiol. 2014, 69, 745-750. [CrossRef]

79. Zhu, Y.; Mao, Y.; Ma, T.; Wen, X. Effect of culture conditions on conidia production and enhancement of environmental stress resistance of Esteya vermicola in solid-state fermentation. J. Appl. Microbiol. 2021, 131, 404-412. [CrossRef] [PubMed]

80. Wang, Y.B.; Wang, C.Y.; Wang, Z.; Xue, J.J.; Li, Z.; Li, J.J.; Gu, L.J.; Hou, J.G.; Lee, M.R.; Ma, R.S.; et al. Laboratory studies on the development of a conidial formulation of Esteya vermicola. Biocontrol Sci. Technol. 2012, 22, 1362-1372. [CrossRef]

81. Xue, J.; Hou, J.; Zhang, Y.; Wang, Y.; Wang, C.; Wang, Z.; Wang, Y.; Sung, C. A method for the enhancement of environmental stress resistance of endoparasitic fungus Esteya vermicola. J. Phytopathol. 2013, 161, 353-358. [CrossRef]

82. Feng, M.G.; Poprawski, T.J.; Khachatourians, G.G. Production, formulation and application of the entomopathogenic fungus Beauveria bassiana for insect control: Current status. Biocontrol Sci. Technol. 1994, 4, 3-34. [CrossRef]

83. Jenkins, N.E.; Prior, C. Growth and formation of true conidia by Metrahizium flavoviride in a simple liquid medium. Mycol. Res. 1993, 97, 1489-1494. [CrossRef] 
84. Wraight, S.P.; Jackson, M.A.; deKock, S.L. Production, stabilization and formulation of fungal biocontrol agents. In Fungal Biocontrol agents_-progress, problems and potential; Butt, T., Jackson, C., Magan, N., Eds.; CABI International: Wallingford, UK, 2001; pp. 253-287.

85. Roberts, D.W.; St. Leger, R.J. Metarhizium spp., cosmopolitan insect-pathogenic fungi: Mycological aspects. Adv. Appl. Microbiol. 2004, 54, 1-70. [CrossRef] [PubMed] 